\title{
Policy Value of Basic Law in The Process of Criminal Investigation by Polri Investigator
}

\author{
Kholid Mawardi ${ }^{1}$ and Anis Mashdurohatun ${ }^{2}$
}

\begin{abstract}
Policy value of basic law of investigation on the handling of an offense by the police investigators is still less than the maximum because public distrust and dissatisfaction factors on the performance of the Police. The purpose of this research isto describe rate policy the basic law, the factors that influence and examine how the investigation should be done on the handling of criminal assault by police investigators in the present and future. The method used in this research is the approach normatife juridical and empirical approaches. Type of research is descriptive. Primary data and secondary data is data used in this study. Methods of data collection in this study using observation, interview and literature study. Analysis of data using qualitative descriptive method. The study states that 1 ) in order to hold the inquiry and investigation, the Investigation Police Investigation Unit and has implemented procedures in accordance with the prescribed rules legislation; 2) The most dominant factor affect the investigation that is a factor of society 3 ) The efforts made in overcoming the barriers that exist, such as by holding socialization and explain the importance of the role of investigator in handling criminal offense.
\end{abstract}

Keywords: Basic Law; Investigation; Investigator.

\section{Introduction}

Indonesian National Police (POLRI) is an institution that is carrying out a public service function. POLRI is demanded to provide the best service to the public by displaying unity professional performance and reliable in the field. Act No. 2 of 2002 on the Indonesian National Police, Article 13 states that the police have the following principal tasks of maintaining security and public order, enforce the law and to provide protection, shelter and community services.

In the formulation of Article 14 paragraph (1) letter g of Act No. 2 of 2002, mentioned that in carrying out basic tasks as referred to in Article 13, the Indonesian National Police assigned to conduct the investigation against all criminal acts in accordance with the law of criminal procedure and other legislation.

Today the rampant criticism of the reality of law enforcement in Indonesia, especially on the performance is incorporated in the Criminal Justice System is a natural thing. These concerns must be seen as a desire on all sides so that there is a change towards the better in the future because there is not a criminal justice system that have stable and fixed for all time can be applied in any country.

1 Student of Master of Law, Universitas Islam Sultan Agung Semarang and Police email Kholidmawardi034@gmail.com

2 Lecturer of Faculty of Law UNISSULA Semarang 
Public disappointment against law enforcement Particularly worrying is the loss of confidence in the investigating authorities (police). Take the form of people do not want to give someone who has committed the crime to the police or the community did not report any incident of Criminal judging, process and execute his own people caught in the act or other issues that are not caught in the act that hopes can be completed by way of meetings or ADR.

This is done because people have too much seeing how people who commit a criminal offense finally freed by the police or other law enforcement officers on the grounds that reported an average of less proof, no evidence, or do not meet the elements of the offense giving rise to the disappointment of the people that report.

Then the other things that affect public confidence in the police investigators is the public perception of the process of investigation conducted by the police, which can be influenced by misconceptions by the public or the media coverage that is understood by the public in frequent criminalization by investigators, thus Investigator Police in conducting the investigation did not meet the legal base value.

\section{Research Methods}

The method used in this research is the approach normatife juridical and empirical approaches. Juridical normatife is an approach that emphasizes the legislation. This approach is used because of issues to be addressed relating to the social reality and the behavior of the investigating authorities in the implementation of the investigation itself. Human behavior is involved in an investigation process is also an application of norms predetermined in the Criminal Code.

This empirical approach used in hopes obtained a clear and complete picture of the background and details of the implementation of criminal investigations by the police, as well as to determine the constraints faced in the implementation of the Police investigation.

Besides, it also wants to be disclosed the real conditions on how the factors of legal and non-legal in the sense of internal rules and regulations exsternal Police investigator who took Markowitz's behavior in the field.

Search data sources of the cases have occurred which are considered of particular concern with regard to justice for the people. So that the necessary regulation to provide a balanced keadian for victims of crime and to the offender itself other than it does not negatively impact the environment.

Data source in this research there are 2 of : Primary data is data obtained from direct research in the field, meaning that the data obtained by jumping directly to the object of research to see the real situation. Secondary data is data obtained from the study of literature, meaning that the data obtained from the study of Law, books, literature, papers, and other materials relating to the writing of this study.

Methods of collecting data in this study using library study or research library, which means collecting the data taken from the materials or books library, but it also conducted ways, namely: a). Observation; Observation is the research process by conducting research directly in the field. In this study, researchers conduct 
observations on the implementation of the investigation of cases in order to realize the value of the basic law of the policy; b) Interview is a verbal debriefing process in which two or more face physically. Researchers conducted interviews with police investigators who handled the investigation of criminal matters in the context of the basic law of value realization; c) literature study is data collection techniques by reading library books.

Analysis of data using qualitative descriptive method, where the discussion of research and results through words based on empirical data obtained. The data obtained in this study is qualitative data, as in this study using qualitative description, then the nonstatistical analysis used.

\section{Results and Discussion}

As already mentioned in the background of this paper, that the policy the value of the basic law in the investigation of the criminal case handling, Police still influenced by the perception that people lack confidence in the performance of the police. This has an impact with less than the maximum results in the handling of cases so caused mismatch between the investigator with the basic values of law.

Act No. 8 of 1981 on Criminal Procedure, giving a role to the Indonesian National Police to carry out the task of inquiry and investigation of criminal offenses (generally) without authorization environmental restrictions as long as they fall within the scope of public law.

So basically the Police by the Code of Criminal Procedure authorized to conduct the investigation against all crime, although the Criminal Procedure Code also provides authority to certain investigators to conduct the investigation in accordance with the special powers granted by law into their own basic law.

As described in the Word of Allah, QS. An Nisa verse 135, which reads:

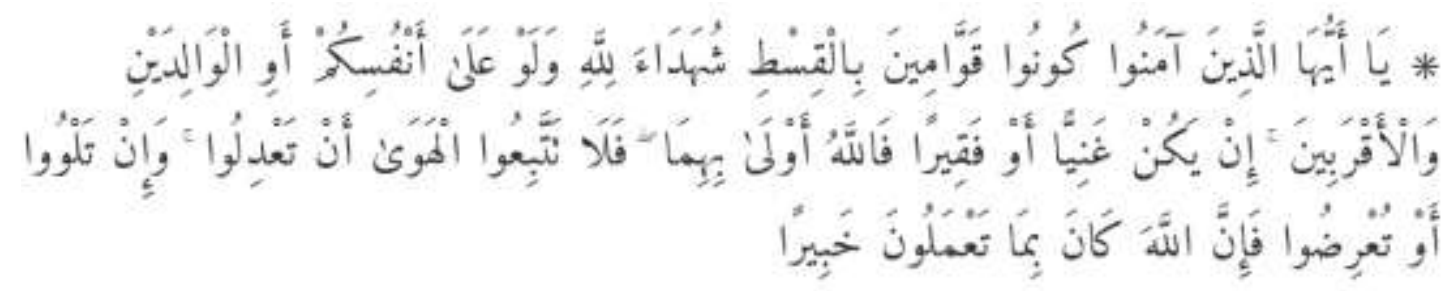

"O you who have believed, be persistently standing firm in justice, witnesses for Allah, even if it be against yourselves or parents and relatives. Whether one is rich or poor, Allah is more worthy of both. So follow not [personal] inclination, lest you not be just. And if you distort [your testimony] or refuse [to give it], then indeed Allah is ever, with what you do, Acquainted".

So we can conclude that the process of investigation together with the investigation will facilitate the process. In this process, it is expected that people can trust completely to the Police and to accept whatever the outcome of the investigation police. The Police has the authority of the Criminal Code, by referring to the basic values of law and legislation in force. 
Conceptually, the essence and meaning of law enforcement lies in harmonizing relations activities that span the 'hierarchy of values in a steady norms and attitudes manifest and acts as a series penjabatan value of the final stage, to create, maintain, and maintaining social peace alive. ${ }^{3}$

Law enforcement is not merely the implementation of the law, but can also factors that influence it, is as follows:

- Legislation factor (Substance Law). In this case limited to the statute.

- Factors Law Enforcement. Parties are formed and applying the law.

- Facilities and amenities factors that support law enforcement.

- Society factors. The environment in which they may apply or applied.

- Cultural factors

As a result of the work, creativity and taste that is based on human initiative in social life.

Of the above-mentioned factors, community factors are the most influential factors in the process of investigation. Their dissatisfaction and distrust of the performance of the police, resulting in the investigation process is not in accordance with the basic values of law and legislation in force.

Indonesia is still valid at common law, customary law is the customary law prevailing in society.

Here is a case of data handled Police investigation Purworejo Period of 2017 until 2018.

Table 1 Data Research and Investigation Police Purworejo 2017-2018

\begin{tabular}{|c|l|c|c|c|}
\hline \multirow{2}{*}{ No. } & \multirow{2}{*}{ Data } & \multicolumn{2}{|c|}{ Year } & \multirow{2}{*}{ Amount } \\
\cline { 3 - 4 } & & 2017 & 2018 & \\
\hline 1 & Investigations & 89 & 51 & 140 \\
\hline 2 & Investigations & 110 & 60 & 170 \\
\hline
\end{tabular}

According to the table 1 above, it is explained that in 2017 and 2018 there were 140 cases of investigation. In the year 2018 , a decrease of $1.6 \%$ compared to 2017 . There was a decrease of cases are caused by insufficient evidence that the case be closed.

According to the table 1 above, it is explained that in 2017 and 2018 amounted to 170 cases. This case is higher by $1.21 \%$ compared with the case investigation. In 2018 decreased due to the case before an investigation, an investigation has been carried out beforehand. The case has been completed at an early stage is the stage of the investigation.

For the investigation of cases in 2018 decreased significantly compared to 2017, amounting to $1.8 \%$.

Based on the above table, it can be said that the performance of the police in handling the case, both the investigation and the investigation has increased. This is evidenced by the decline in cases in 2018.

Here is an example of a case that occurred in Purworejo investigation:

3 Soejono Soekanto 1979.Pengantar Penelitian Hukum UI Press Jakarta. 
There has been a criminal offense of theft as defined in Article 363 of the Criminal Code which occurred on Saturday, May 5, 2018 approximately at $04.00 \mathrm{pm}$ in the house Br. Sugeng Riyanto Kp. Brengkelan Ex. Purworejo Rt. 04 Rw. 01 district. Purworejo district. Purworejo committed by the suspect Bunadi namely Ari Bin Sutomo. As at around $04.00 \mathrm{pm}$ when the thief return to play billiard later Ari back home on foot, while on the Ari saw a house with an open window.

Ari approached the house and headed for the opened window. From the window there are some HP is right under the window, and when the homeowner was sleeping. Ari left hand take three (3) pieces of HP is 1 (one) unit of HP brand Xiaomi white, 1 (one) unit of HP brand Xiaomi white and one (1) HP brand ADVAN white color that is in place. For the incident the victim suffered a loss of Rp. 3.000.000, - (three million rupiah).

Article provided to ensnare such cases is Article 363 of the Criminal Code (Act No. 8 of 1981).

Based on these cases, the police have been conducting an investigation in order to provide appropriate punishment for the thieves with the applicable legislation. With strong evidence and no perpetrators have given punishment in accordance with the criminal offense which is done. That the Police conducted investigations conducted in accordance with the legal basic rate policy and legislation in force. There is no exception that the thief is the son of an officer or children of influential people in government agencies. POLRI remains ensnared with the applicable chapter in accordance with the legal norms of the legislation.

\section{Closing}

\subsection{Conclusion}

Policy value in the basic law of investigation on the handling of an offense by the police investigators is still less than the maximum and not in accordance with the basic values of law and regulations. This was due to factors distrust and community dissatisfaction with police performance.

Community factors still dominate in the investigation process. To overcome this, the Police are actively socializing and convince people to give up all the process of handling the investigation to the Police. In order to obtain the result that is fair, clear and remain guided by the legislation in force.

\subsection{Suggestion}

- For Police. Active socializing and explaining the importance of the role of investigator in handling criminal offense.

- For Society. Always trust and supervise the performance of the police. Active ask if find something less obvious, or not in accordance with the applicable legislation

\section{Bibliography}

[1] Andi Hamzah 2013 Hukum Acara Pidana Indonesia Sinar Grafika Jakarta 
[2] Hanitijo Soemitro Rony 1998 Metode Penelitian Hukum dan Jurimetri Ghalia Indonesia Jakarta

[3] H.B. Sutopo 1998 Metodologi Penelitian Hukum Kualitatif Bagian II UNS Press Surakarta.

[4] Soejono Soekanto 1979 Pengantar Penelitian Hukum UI Press Jakarta.

[5] Act No. 13 of 1961 On the State Police Basic Provisions

[6] Act No. 8 of 1981 on the Law of Criminal Procedure

[7] Act No. 2 of 2002 on the Police of the Republic of Indonesia 